Volume 8, Issue 1, 301 - 312.

ISSN: 2165-8714

http://www.eu-jer.com/

\title{
The Effectiveness of Intercultural Sensitivity Development Activities Integrated with Scientific Research Methods Course *
}

\author{
Ibrahim Tuncel ** \\ Pamukkale University, TURKEY
}

Received: December 15, 2018 - Revised: January 3, 2019 - Accepted: January 13, 2019

\begin{abstract}
It can be said that effective development of intercultural sensitivity depends on the regulations and practices in the curriculum. Integrated program implementations are seen as one of the ways of regulation. In the study, a nested integration model was used in a single discipline. In this context, scientific research methods are considered as a discipline, and the achievements of this discipline and intercultural sensitivity development activities are integrated. Understanding different cultures correctly and not being prejudiced are very important for the development of intercultural sensitivity. Scientific research methods course provides students with scientific attitudes and behaviors. In this course, it is thought that students will be able to develop sensitivity by examining different cultures with scientific attitudes and behaviors. In this context, it is aimed to reveal the effectiveness of intercultural sensitization development activities integrated with scientific research methods course gains. The quasi-experimental design with a pretest-posttest and a control group was used in the study. The study group comprised of 86 second-grade students in the English Teacher Training Department. In order to measure the intercultural sensitivities of the students before and after the test procedure, the five-point likert type "Intercultural Sensitivity Scale" developed by Chen and Starosta and adapted to Turkish by Bulduk, Tosun and Ardıç was used as data collection tool. It is concluded that the curriculum of scientific research methods integrated with intercultural sensitivity development activities is effective in developing students' intercultural sensitivities.
\end{abstract}

Keywords: Integrated curriculum, intercultural sensitivity, prospective English teachers, nested model.

To cite this article: Tuncel, İ. (2019). The effectiveness of intercultural sensitivity development activities integrated with scientific research methods course. European Journal of Educational Research, 8(1), 301-312. doi: 10.12973/eu-jer.8.1.301

\section{Introduction}

Teacher training programs that would be efficient to provide the prospective teachers with the intercultural competence are considered one of the key competences of the 21st century because teachers encounter more with students from different cultures day by day and this situation requires the teachers to have intercultural competence. In democratic educational institutions, intercultural competence should be acknowledged as a feature that should be provided via education instead of a competence that is expected to emerge spontaneously, so studies conducted by curriculum development experts on how curricula should be organized to provide an individual to have intercultural competence effectively are of great importance.

There are numerous studies in the literature aimed at determining the factors affecting the development of intercultural competence. Multifarious factors such as the lack of intercultural education tradition and the under termination of the appropriate pedagogical approaches, school culture, determination of objectives from a narrow perspective, unfamiliarity of teachers and students with the concept of intercultural competence affect the development of intercultural competence (Malazonia, Maglakelidze, Chiabrishvili \& Gakheladze, 2017; Papiniu, 2016).

\section{Intercultural Competence and Sensitivity}

Firstly, it would be beneficial to explain the concepts of intercultural competence and intercultural sensitivity. Deardorff (2004) defines intercultural competence as the ability to establish effective and appropriate communication in intercultural environment based on intercultural knowledge, skills and attitudes. According to Hesse and Göbel (2007), intercultural competence comprises of multidimensional cognitive, emotional and psychomotor components. In

\footnotetext{
* This study was presented as an oral presentation at 2017 IV. International Eurasian Educational Research Congress at Pamukkale University, Denizli.

** Correspondence:

Ibrahim Tuncel , Pamukkale University, Department of Educational Science, Denizli, Turkey.

$\bowtie$ ituncel20@gmail.com
} 
addition, intercultural competence also includes the explanatory information such as communicative and interactional sub-competences, and the cultural competences and the general competences to be acquired. Chen and Starosta (2000) call the emotional process for intercultural communicative competence, "intercultural sensitivity", cognitive process, "intercultural awareness" and behavioral process as "intercultural adroitness".

This study is limited to the intercultural sensitivity, which comprises the emotional dimension of intercultural competence. Intercultural sensitivity is an emotional feature that contains the close up of individuals with cultural differences unprejudiced, without using stereotypes, understanding, knowing and respecting each other (Spitzberg \& Changnon, 2009; Hesse \& Göbel, 2007; Auernheimer, 2008; Byram, Gribkova \& Starkey, 2002). Intercultural sensitivity is defined as the ability to develop a positive emotion that promotes the appropriate and effective behavior in intercultural communication for making sense of and evaluating the cultural differences (Chen \& Starosta, 2000).

\section{Interculturality in Turkish Educational Context}

Providing the learner with desirable features via learning experiences is carried out by the curricula (Demirel, 2004). There are some indicators that efforts are being made to raise individuals with intercultural sensitivity via curricula in Turkey like in other democratic societies. In the national qualification framework for higher education published by the Council of Higher Education (2011), the qualifications "know national and international cultures" and "lives in different cultures and adapts to social life" are listed among the teacher training and education science qualifications. On the other hand, according to the "Personal and Professional Qualifications" in general qualifications of the teaching profession determined by the Ministry of National Education, the qualification "makes an effort for ensuring that the students learn and develop at maximum by considering their social and cultural differences, their performances and interests" (Ministry of National Education, 2008, p. 10). It is clearly understood that the objective of raising individuals with intercultural sensitivity is among the objectives of both higher education and the Ministry of National Education. In this respect, it can be argued that providing intercultural competence should be among the objectives of all teachertraining programs.

In addition, the importance of learning a language cannot be denied in understanding the values and attitudes related to the culture in acquiring intercultural competence. In addition, it can be argued that intercultural competence is influential in language learning. Language learning and intercultural competence affect each other, especially, when the relation between language and culture is considered, the objectives of English Teacher Training Curricula should include intercultural sensitivity, which expresses the emotional dimension of intercultural competence. According to Byram (2009), the "discovering" and "understanding" skills, which increases the awareness in different cultures and cultural identities, should be focused on in foreign language training and the instruction should be planned to include objectives, materials and methods to develop intercultural competence.

\section{Interculturality in Language Teaching and Teacher Training}

Research on the intercultural competences of language teachers in the world has primarily focused on researching cultural awareness (Larzen- Östermark, 2009; Sercu, 2006). There are studies investigating the link between teacher education and interculturalism (Dooly \& Villanueva, 2006; Larzen-Östermark, 2009). A research on prospective teachers in Finland emphasized that cultural aspects are not addressed effectively in teacher education programs (Larzen-Östermark, 2009), while Jing (2013) explored the perceptions of English teachers about two concepts defended in China's English curriculum, which are awareness and intercultural competence (IC). These two concepts are related to each other. In addition, it was emphasized that English teachers are responsible for teaching intercultural experiences, grammar and thinking, attitudes, intercultural communication skills and world values. In a study by Kostková (2011) in the Czech Republic, he examined the effect of an intercultural course on pre-service English teachers. The study showed that prospective teachers showed statistically significant changes in the IC's two main components, which are knowledge and skills. Some other studies have examined intercultural competence (IC) levels of pre-service teachers abroad and revealed that pre-service teachers develop a more positive attitude towards cultural difference (Dooly, 2010; Tang \& Choi, 2004). Research shows the importance of integrating intercultural teachers into teacher education programs and helping teacher candidates develop their ICs.

In Turkey, there are many studies that deal with intercultural competence or the sensibilities of students studying at English language teaching departments. In Harmandaoğlu's study (2013), it was found that pre-service English teachers developed their knowledge and attitudes dimension of intercultural communication skills through Twitter values reveal that any progress. In Baykara's (2010) research, it was found that when students have learned that the culture of foreign language they learn, it will provide great convenience in learning the language itself. The attitudes of university preparatory class students who learn English as a foreign language by Güven (2015) were investigated against intercultural communication competence learning. In the study, it was found that students generally have a positive attitude towards intercultural communication. In the study conducted by Sıkı (2014), it has been investigated whether there is a difference in the school of foreign languages applying a program based on the European Languages Common Framework Program and among the school of foreign languages students who have only language skillsoriented goals and aims. As a result of the study, it was found that the foreign language students of the School of Foreign Languages applying a program based on the European Languages Common Framework Program have a 
positive effect on the sensitivity and towards target culture. In Turan's (2015) study, it was determined that almost all prospective teachers agreed that foreign language courses were important for the elimination of intercultural biases and disagreements.

As a result of the research conducted by Gencer (2009), it was found that the German pre-service teachers did not undergo a sufficient change in their views and opinions about the German language and culture at the end of their undergraduate education. In the study by Yücel (2016), the effect of pre-service English teachers' intercultural education on intercultural education perceptions in ELT was investigated. The findings showed that a carefully designed Intercultural Training course could help prospective teachers to question interculturalism not only in comprehension and practice, but also in their global perspectives and ideas about education. However, the findings also show that the duration of the intercultural education (IE) course is not sufficient to achieve all goals of education. In the study conducted by Tuncel and Paker (2018), it was concluded that senior English pre-service teachers had high intercultural sensitivity perception and that intercultural communication course was effective in developing intercultural sensitivity of English teacher candidates.

\section{Integrated Curriculum and Interculturality}

Intercultural sensitivity requires an interdisciplinary approach since it contains culture. According to Deardorff (2006), adding "Intercultural Competence" as a separate course to the curriculum may not be effective for the development of intercultural competence, which is a multidimensional and spiral process. Instead, to what extent intercultural competence objective could be integrated in the present curriculum should be investigated. An integrated education approach should be followed for the development of intercultural competence and its different dimensions should be realized at different levels and via different learning styles.

It can be said that although there are studies about ELT students and intercultural competence, it is clear that intercultural competence tajes a very limited place in curriculums and programs (Yücel, 2016). When the English teacher training graduate curriculum is examined, it is understood that although there are qualifications towards developing intercultural sensitivity in the qualifications of the curriculum, there is not any specific course for developing intercultural sensitivity in students.

When the literature is reviewed, it can be seen that there are many different models on how to carry out integration (Drake, 1993; Fogarty, 1991; Jacobs, 1989). Fogarty (2002) defined 10 separate models for integrated curriculum. He discussed the integration process in three levels. The first level is the integration of the curriculum within a single discipline (special-topic model). The teachers may plan the curriculum using the fragmented, connected or nested models. The second one is the integration of the model between more than one disciplines (across several disciplines model). The third level is the integration via immersed and networked models, which increases certain awarenesses of the learners.

Studies on integrated curriculum with regard to intercultural competence or sensitivity developing (Ferguson-Patrick, Reynolds, and Macqueen, 2018; Hirotani and Fujii, 2015; Li, 2017; McRae and Ramji, 2017; Taraban-Gordon and Page, 2017) have been encountered recently in the literature. In a study by Hirotani and Fujii (2015), it was ascertained that the integration of the intercultural collaborative activities with the foreign language curriculum contributed to students' reflection of what they had learned about cultural differences and similarities. Ayvaz-Tuncel (2009) concluded that the communication, cooperation and social problem solving skills and the self-respect of the experimental group, which was administered an integrated curriculum developed more than the control group.

The research for determining the foreign tendencies on integrated curriculum studies by Yeşilpınar-Uyar (2016) examined doctoral theses in many countries and dissertations on integrated curriculum between 2001 and 2015 . The research concluded that research on integrated curriculum design and implementation in the higher education are required. It can be argued that the studies to reveal the effect of the integrated curriculum in Turkey are not adequate. There are not any studies on developing intercultural competence or sensitivity using integrated curriculum in Turkey.

\section{Research Methods Course and Intercultural Sensitivity}

In the examination for determining which discipline would be appropriate to integrate the intercultural sensitivity development activities, the appropriateness of the objectives of the Scientific Research Methods course was decided because the objective of the Scientific Research Methods course is to provide students with scientific behaviors. Karasar (1994) explains some of the scientific behaviors as follows: open-mindedness, viewing events without prejudice, ability to delay the decision until sufficient evidence is collected, and considering, searching and finding the reasons (circumstances) that create the events in the examination of those events. These behaviors are the features that should be present in individuals with intercultural sensitivity.

In addition to this, scientific research methods include the ability to make observations, to interpret, to analyze and to evaluate objectively. Therefore, it can be said that the curriculum of scientific research methods includes the acquisitions that will support the development of intercultural sensitivity. Understanding different cultures correctly and not being prejudiced is very important for the development of intercultural sensitivity. Scientific research methods 
course provides students with scientific attitudes and behaviors. In this course, it is thought that students will be able to develop sensitivity by examining different cultures with scientific attitudes and behaviors.

The aim of this course is to reveal the effectiveness of intercultural sensitivity development activities integrated with scientific research methods course. In accordance with this aim, answers for the following research questions were sought:

- What are the intercultural sensitivity perception levels of students in the English training department at the beginning and at the end of the semester?

- Is there a significant difference in the intercultural sensitivity scale scores of the students attending scientific research methods course with the students who participate in the intercultural sensitivity development activities integrated with the scientific research methods course gains?

\section{Research Model}

\section{Methodology}

In the present study, it was decided to use Fogarty's (1991, 2002) integrated program models, which is a nested model in a discipline. The nested integration model monitors the training program with three-dimensional glasses and targets multiple dimensions of a course. In the nested model, attention is drawn to more than one area at the same time, enriched and improved learning paths are provided. Social skills and thinking skills are targeted within a subject area. The main aim to select this model is that it is aimed to develop intercultural sensitivity development in scientific research methods course. This model provides enriched learning opportunities in terms of both scientific method and different cultures. For example, in the course of the interview method, students had to discuss the cultural differences and to discuss the questions from different cultures with individuals from other countries.

In addition to the outcomes of the scientific research methods course, intercultural sensitivity developing activities were inserted into the course and thus enriched and improved learnings were aimed at. To determine the effect of integration, a quasi-experimental design with a pretest-posttest and a control group was preferred as the test model in the study. Since the aim of the study is to compare the intercultural sensitivity levels of the experimental group, which was administered the intercultural sensitivity training activities integrated with the outcomes of the course, and the control group that was not administered these activities, this design was preferred as the experimental design allows for these kinds of comparisons.

Table 1. The quasi-experimental design with a pretest-posttest and a control group

\begin{tabular}{llll}
\hline Group & Pretest & Practice (2 hours/ week, totally: 12 weeks, 24 hours) & Posttest \\
\hline \multirow{2}{*}{ Experimental } & Intercultural & Intercultural sensitivity development activities integrated & Intercultural \\
& Sensitivity Scale & with scientific research methods course & Sensitivity Scale \\
\hline Control & Intercultural & Scientific Research Methods Course Curriculum & Intercultural \\
& Sensitivity Scale & & Sensitivity Scale \\
\hline
\end{tabular}

\section{Study Group}

The study group of this research comprises of 86 second-year students attending the "Scientific Research Methods (Compulsory)" course in 2015-2016 academic year, spring semester, in Pamukkale University Faculty of Education English Language Education Department.

Scientific research methods course is only a course in the 2nd grade English teaching program. Therefore, the universe of the study is 2nd grade students in English Language Teaching. The decision on which group of students will be the control group and which group will be experimental group determined by the lottery randomly. The students attending the 2 / B branch (43) were the experimental group and the students who attended the 2 / A branch (43) formed the control group.

Table 2. Distribution of the socio-demographic properties of the students participated in the study

\begin{tabular}{|c|c|c|c|c|c|c|c|}
\hline \multirow[b]{2}{*}{ Variable } & \multirow[b]{2}{*}{ Category } & \multicolumn{2}{|c|}{ Experimental } & \multicolumn{2}{|c|}{ Control } & \multicolumn{2}{|c|}{ Total } \\
\hline & & $f$ & $\%$ & $f$ & $\%$ & $\mathbf{f}$ & $\%$ \\
\hline \multirow{2}{*}{ Sex } & Female & 31 & 72.1 & 37 & 86.0 & 68 & 79.1 \\
\hline & Male & 12 & 27.9 & 6 & 14.0 & 18 & 20.9 \\
\hline \multirow{3}{*}{ The settlement they had lived for the longest time } & Province & 14 & 32.6 & 15 & 34.9 & 29 & 33.7 \\
\hline & County & 28 & 65.1 & 26 & 60.5 & 54 & 62.8 \\
\hline & Abroad & 1 & 2.3 & 2 & 4.7 & 3 & 3.5 \\
\hline \multirow{2}{*}{ The place they live is multicultural } & Yes & 14 & 32.6 & 11 & 25.6 & 25 & 29.1 \\
\hline & No & 29 & 67.4 & 32 & 74.4 & 61 & 70.9 \\
\hline \multirow{2}{*}{$\begin{array}{l}\text { They have lived with people from different cultures, due to any } \\
\text { reason. }\end{array}$} & Yes & 33 & 76.7 & 28 & 65.1 & 61 & 70.9 \\
\hline & No & 10 & 23.3 & 15 & 34.9 & 25 & 29.1 \\
\hline
\end{tabular}


When Table 2 is examined, it is seen that both groups have similar properties when the students in the experimental and the control groups are compared with regard to variables that could affect their intercultural sensitivity development. A great majority of the students participating in the study (experimental $=67.4 \%$, control $=74.4 \%$ ) expressed that the place they had lived for a long time was not multicultural, however, they have been together with people from different culture due to any reason (education, touristic voyages, living there, etc.) (experimental = 76.7\%, control=65.1\%).

\section{Data Collection Tools}

In order to measure the students' intercultural sensitivity levels, the five-point likert type "Intercultural Sensitivity Scale" was used as the data collection tool, which was developed by Chen and Starosta (2000) and adapted into Turkish by Bulduk, Tosun and Ardiç (2011). In the adaptation study, the Cronbach's Alpha internal consistency coefficient of the scale was calculated 0.72. In this study, on the other hand, Cronbach's Alpha was found 0.86. The original scale comprises of five dimensions. During the validity study, it was ascertained that the distribution of the items to the subdimensions with regard to their factor load values was not consistent with the original version in the version adapted to Turkish culture. In the first adaptation study of the scale, Chen was contacted and gave an approval that the scale could be used unidimensionally (Üstün, 2011). Therefore, the "Intercultural Sensitivity Scale", which comprises of five dimensions in its original version, was decided to be used unidimensionally in this study. The scale comprises of 24 items and it is in five-point likert form, in which the participants decided as " $5=$ Strongly agree", " $4=$ Agree", " $3=$ Partially agree", "2= Disagree", "1= Strongly disagree" for their answers to the expressions.

\section{Test Procedures}

- The intercultural sensitivity scale was carried out for the students in the experimental and the control group at the beginning of the semester as pretest.

- The students in the experimental group were given the scientific research methods course curriculum integrated with research-review activities on different cultures for 12 weeks. The integrated curriculum aimed at ensuring that the students structured the information by gaining real life experiences. Activities as group work were conducted.

- Any intervention was not made to the "Scientific Research Methods" course in the control group, and the course had advanced in line with its own outcomes.

- The courses had been conducted with the Teaching via Research-Review Strategy, in both the experimental and the control group.

- At the end of the experimental procedure, the intercultural sensitivity scale was carried out for the students in the experimental and the control group as posttest.

- In addition, the mean achievement scores for the scientific research methods course for both groups were compared.

Table 3. Examples from the activities integrated with scientific research method course

\begin{tabular}{ll}
\multicolumn{1}{c}{$\begin{array}{c}\text { Scientific Research Method Course } \\
\text { Outcomes }\end{array}$} & \multicolumn{1}{c}{$\begin{array}{c}\text { Activities Integrated with Course Outcomes } \\
\text { ACTIVITIES }\end{array}$} \\
\hline $\begin{array}{l}\text { Outcome 4: Explains the properties of a } \\
\text { researchable problem }\end{array}$ & $\begin{array}{l}\text { The students discuss whether the research problems about knowing or } \\
\text { comparing different cultures are researchable }\end{array}$ \\
\hline $\begin{array}{l}\text { Outcome 5: Explains the points to be paid } \\
\text { attention in writing a problem sentence } \\
\text { and sub problems }\end{array}$ & $\begin{array}{l}\text { Writing the problem sentence and the sub problems of a research about } \\
\text { knowing or comparing different cultures (Group Study) }\end{array}$ \\
\hline $\begin{array}{l}\text { Outcome 6: Knows a variable and variable } \\
\text { types }\end{array}$ & $\begin{array}{l}\text { Examination of factors affecting culture with regard to an independent variable } \\
\text { (e.g. influence of geographical features on cuisine or clothing, etc.) }\end{array}$ \\
\hline $\begin{array}{l}\text { Outcome 9: Knows the document review } \\
\text { as a data collection method }\end{array}$ & $\begin{array}{l}\text { Finding and reviewing documents on different cultures (Movies, Photographs, } \\
\text { etc.), discussing the point to be paid attention in analyzing documents (group } \\
\text { study) }\end{array}$ \\
\hline $\begin{array}{l}\text { Outcome 10: Explains the properties of } \\
\text { the interview method }\end{array}$ & $\begin{array}{l}\text { Preparing interview questions to conduct an interview with an individual from a } \\
\text { different culture; making the interview over scale media and recording the } \\
\text { interview; discussing the problems encountered during the interview; writing a } \\
\text { report about the reflections of cultural differences, which arose during the } \\
\text { interview, on the interview }\end{array}$ \\
\hline $\begin{array}{l}\text { Outcome 11: Explains the properties of a } \\
\text { survey, one of the data collection tools }\end{array}$ & $\begin{array}{l}\text { Preparing a "Survey" suitable for the determined research aim about knowing or } \\
\text { comparing different cultures. Administration of the survey to a small group over } \\
\text { social media and getting response. Discussing the points to be paid attention } \\
\text { while preparing a survey, facilitating the experience obtained in the process. }\end{array}$ \\
\hline $\begin{array}{l}\text { Outcome 12: Identifies the validity and } \\
\text { reliability properties of assessment tools }\end{array}$ & $\begin{array}{l}\text { Discussing how different cultural properties would influence the validity or } \\
\text { reliability of a research. } \\
\text { (e.g., the survey items containing culture specific senses) }\end{array}$ \\
\hline
\end{tabular}


While the "interview method" was administered in the scientific research methods course, both "individual interviews" and "focus group interviews" with individuals from different cultures were designed by the students. The person or persons to be interviewed were found by the students over social media and the interviews were conducted on the internet. For instance, when investigating the food culture of a country, an interview was made with a cook living in that country. However, the students, generally, got in contact with university students from the countries they were researching. The internet and the social media were used when the survey preparation and application subject was being discussed in the course. In this respect, the internet medium had become an important instrument for the students to find a medium to interact with other individuals from different cultures.

The scientific research methods course activities were conducted with collaborative studies and the students performed the focus group interviews with the university students from the countries they were studying using communication tools such as Facebook and Skype. In addition, focus group interviews were conducted with the foreign students in the English training department on culture. Through these activities, the students both had the opportunity to practice the theoretical knowledge about "focus group interview" they obtained by course, and they benefited from the outcomes of the intercultural interaction environment.

\section{Analyzing of Data}

In order to find out the suitable test statistics, the Shapiro-Wilk test results were examined to determine the appropriate test statistic and it was found that the scores on the dependent variable (intercultural sensitivity) exhibited normal distribution in each subgroup.

The independent samples t-test was used to compare the mean scores of the experimental and chrono-control group students from the initial (pretest) intercultural sensitivity scale. The two-factor ANOVA for mixed measurements is used to test the effectiveness of the experimental procedure applied in two-factor mixed patterns in which unrelated measurements depending on the process groups and time-based repeated measures are mentioned (Büyüköztürk, 2018).

The Two-way ANOVA for Mixed Measures was used to determine whether the students' intercultural sensitivity perception levels varied with regard to their participation in the intercultural sensitivity training activities integrated with the scientific research methods curriculum. The first factor consists of two levels, that is, two process groups, namely the experimental and control groups. The second factor defines pre- and post-test measurements (pretestposttest).

The lowest score to be obtained from the scale is 24 points while the highest is 120 points. Arithmetic means were interpreted according to these values. In the interpretation of arithmetic mean values, it was benefited from the determination of equal intervals which are low, middle and high by dividing the score between the lowest value which can be taken from the scale and the highest value into three equal parts. According to this; Interdisciplinary sensitivity perception at the lower level between 24 and 56 points, intercultural sensitivity perception at the level of 57 - 88 points, and 89 - 120 point ranges were evaluated as having a high level of intercultural sensitivity perception. The interval levels for item means are 1.0 - 1.80 for "Strongly disagree", 1.81 - 2.61 for "Disagree", 2.62 - 3.42 for "Partially agree", 3.43 - 4.23 for "Agree", and 4.24 - 5.00 for "Strongly agree".

\section{Findings}

What are the intercultural sensitivity perception levels of the students in the English training department at the beginning and at the end of the semester?

Numerous factors which influence the students' intercultural sensitivity development can be mentioned. Being in contact with different cultures, experiences with different cultures, prejudices, training received, etc. may affect sensitivity development so, the students' intercultural sensitivity perception levels being at a certain level at the beginning of the test procedures could be explained by influence of these factors. Besides, it would be misleading to explain intercultural sensitivity development with the effect of a single factor. The descriptive statistics related to the intercultural sensitivity perception levels of the second-year English Training Department students are presented in Table 4.

Tablo 4. Students' intercultural sensitivity perception levels

\begin{tabular}{llllllll}
\hline \multirow{2}{*}{ Group } & & \multicolumn{2}{c}{ Mean of items } & \multicolumn{2}{c}{ Std. Deviation } \\
\cline { 2 - 7 } & N & Pre & Post & Pre & Post & Pre & Post \\
\hline Experimental & 43 & 3.62 & 4.13 & 87.04 & 99.20 & 10,07 & 10,19 \\
Control & 43 & 3.66 & 3.72 & 87,93 & 89,27 & 9,41 & 9,23 \\
\hline Total & $\mathbf{8 6}$ & $\mathbf{3 . 6 4}$ & $\mathbf{3 . 9 2}$ & $\mathbf{8 7 . 4 8}$ & $\mathbf{9 4 . 2 4}$ & $\mathbf{9 . 7 0}$ & $\mathbf{1 0 . 8 8}$ \\
\hline
\end{tabular}


As it is seen in Table 4, it is found that while the intercultural sensitivity levels of the students in both the experimental group ( $\overline{\mathrm{X}}=87.04)$ and the control group ( $\overline{\mathrm{X}}=87.93)$ at the beginning of the semester were moderate, the students in the experimental group ( $\overline{\mathrm{X}}=99.20)$ had a higher level of intercultural sensitivity perception than the control group $(\overline{\mathrm{X}}=89.27)$ when the arithmetic means of the scores obtained from the intercultural sensitivity scale were compared.

Is there a significant difference in the intercultural sensitivity scale scores of the students attending the scientific research methods course with the students participating in the scientific research methods integrated with the cultural development activities?

It can be asserted that the students participated in the study have some similarities with regard to the sociodemographic properties and to some factors that could affect intercultural sensitivity development (the multiculturality of the place lived, experience with different cultures). In addition, both instructors of the scientific research methods course in both experimental and control groups used the "teaching via research-review" strategy. Thus, the effect of the integrated activities on intercultural sensitivity development was determined, which was the main purpose of the study.

Table 5. The t-test results for the pretest mean scores of the intercultural sensitivity scale

\begin{tabular}{lcccccc}
\hline & $\mathbf{N}$ & $\overline{\mathbf{x}}$ & Std. Deviation & $\mathbf{d f}$ & $\mathbf{t}$ & $\mathbf{p}$ \\
\hline Experimental Group & 43 & 87.04 & 10.07 & \multirow{2}{*}{84} & .420 & .675 \\
Control Group & 43 & 87.93 & 9.41 & & & \\
\hline$p>.05$ & & & & & &
\end{tabular}

When the data in Table 5 are examined, it is seen that there is not any statistically significant difference in the students' intercultural sensitivity scale pretest scores for both the experimental and the control group, $t(84)=.420$, $p>.05$. This finding indicates that the intercultural sensitivity perception levels of the students in both groups were not different statistically at the beginning. The results of the ANOVA, conducted to reveal the effect of the test procedure are presented in Table 6.

Table 6. ANOVA results for intercultural sensitivity scale pretest-posttest scores

\begin{tabular}{|c|c|c|c|c|c|c|}
\hline Source of Variance & Sum of Squares & df & $\begin{array}{c}\text { Mean } \\
\text { Square }\end{array}$ & $\mathbf{F}$ & $\mathbf{p}$ & $\begin{array}{c}\text { Partial Eta } \\
\text { Squared }\end{array}$ \\
\hline Interparticipant & 14658.42 & 85 & & & & \\
\hline Group & 879.773 & 1 & 879.773 & 5.363 & $.023 *$ & .060 \\
\hline Error & 13778.651 & 84 & 164.032 & & & \\
\hline Intraparticipant & 5371.5 & 86 & & & & \\
\hline Test (Pretest-Posttest) & 1962.564 & 1 & 1962.564 & 76.258 & $.000 *$ & .476 \\
\hline Group*Test & 1257.122 & 1 & 1257.122 & 48.847 & $.000^{*}$ & .368 \\
\hline Error & 2161.814 & 84 & 25.736 & & & \\
\hline Total & 20029.92 & 171 & & & & \\
\hline
\end{tabular}

When Table 6 is examined, it is found that there is a significant difference between the sums of the pretest scores and posttest scores of both groups at the end of the measurements of the experimental and the control group (discarding the differences between the successive measurements): $F(1,84)=5.36, p<.05$. It is also found that there is a significant difference between the means of the successive measurements (a difference between pretest and posttest), without differentiating between the experimental and the control groups: $F(1,84)=76.25, p<.05$. It is ascertained that the change in the successive (iterative) measurements (pretest and posttest scores) is significant with regard to procedure groups (as experimental and control): $F(1,84)=48.84, p<.05$. It is understood that the intercultural sensitivity training activities integrated with the scientific research methods course outcomes, which provide more benefit, are also more effective in increasing students' intercultural sensitivity perception levels, when compared to the scientific research method course activities. 
Table 7. Items which has change in their levels, with regard to the intercultural sensitivity level item mean scores, administered at the beginning and at the end of the semester to the students in the experimental group

\begin{tabular}{|c|c|c|}
\hline $\begin{array}{c}\text { The items whose mean scores changed in } \\
\text { the Pretest-posttest }\end{array}$ & $\begin{array}{l}\text { Pre-test } \\
\text { mean scores }\end{array}$ & $\begin{array}{l}\text { Post-test } \\
\text { mean scores }\end{array}$ \\
\hline 1. I enjoy interacting with people from different cultures. & 4.04 & 4.46 \\
\hline $\begin{array}{l}\text { 3. I am pretty sure of myself in interacting with people from different } \\
\text { cultures. }\end{array}$ & 3.34 & 3.76 \\
\hline $\begin{array}{l}\text { 4. I find it very hard to talk in front of people from different cultures. } \\
\text { (Reverse Code) }\end{array}$ & 3.25 & 3.86 \\
\hline $\begin{array}{l}\text { 5. I always know what to say when interacting with people from different } \\
\text { cultures }\end{array}$ & 3.09 & 3.46 \\
\hline $\begin{array}{l}\text { 6. I can be as sociable as I want to be when interacting with people from } \\
\text { different cultures. }\end{array}$ & 3.13 & 3.69 \\
\hline 7. I don't like to be with people from different cultures. (Reverse Code) & 3.58 & 4.39 \\
\hline $\begin{array}{l}\text { 9. I get upset easily when interacting with people from different cultures. } \\
\text { (Reverse Code) }\end{array}$ & $\begin{array}{c}2.58 \\
\text { (Agree) }\end{array}$ & $\begin{array}{c}3.79 \\
\text { (Disagree) }\end{array}$ \\
\hline $\begin{array}{l}\text { 11. I tend to wait before forming an impression of culturally-distinct } \\
\text { counterparts. }\end{array}$ & 3.30 & 4.09 \\
\hline $\begin{array}{l}\text { 15. I often feel useless when interacting with people from different } \\
\text { cultures. (Reverse Code) }\end{array}$ & 3.90 & 4.39 \\
\hline 16. I respect the ways people from different cultures behave. & 4.11 & 4.41 \\
\hline 17. I try to obtain as much information as I can when interacting with & 3.40 & 4.30 \\
\hline people from different cultures. & Partly Agree & $\begin{array}{l}\text { Strongly } \\
\text { Agree }\end{array}$ \\
\hline $\begin{array}{l}\text { 18. I would not accept the opinions of people from different cultures. } \\
\text { (Reverse Code) }\end{array}$ & 4.06 & 4.62 \\
\hline $\begin{array}{l}\text { 19. I am sensitive to my culturally-distinct counterpart's subtle meanings } \\
\text { during our interaction. }\end{array}$ & 3.09 & 3.46 \\
\hline 20. I think my culture is better than other cultures. (Reverse Code) & $\begin{array}{c}2.34 \\
\text { Agree }\end{array}$ & $\begin{array}{l}3.65 \\
\text { Disagree }\end{array}$ \\
\hline $\begin{array}{l}\text { 21. I often give positive responses to my culturally different counterpart } \\
\text { during our interaction. }\end{array}$ & 3.95 & 4.41 \\
\hline $\begin{array}{l}\text { 22. I avoid those situations where I will have to deal with culturally- } \\
\text { distinct persons. (Reverse Code) }\end{array}$ & $\begin{array}{l}3.40 \\
\text { Partly Agree }\end{array}$ & $\begin{array}{c}4.27 \\
\text { Strongly } \\
\text { Disagree }\end{array}$ \\
\hline $\begin{array}{l}\text { 23. I often show my culturally-distinct counterpart my understanding } \\
\text { through verbal or nonverbal cues. }\end{array}$ & 3.76 & 4.32 \\
\hline $\begin{array}{l}\text { 24. I have a feeling of enjoyment towards differences between my } \\
\text { culturally-distinct counterpart and me. }\end{array}$ & 3.81 & 4.34 \\
\hline
\end{tabular}

When the Table 7 is examined, it is understood that while students answered the scale items "I get upset easily when interacting with people from different cultures" and "I think my culture is better than other cultures" as "Agree" before the experiment, a significant change was found in these answers after the experiment and the students answered these items as "disagree". It is another interesting finding that before the curriculum activities, the students answered the items "I try to obtain as much information as I can when interacting with people from different cultures" and "I avoid those situations where I will have to deal with culturally-distinct persons" as "partially agree", while they answered these items as "strongly agree" after the activities.

Table 8. Items which does not have change in their levels, with regard to the intercultural sensitivity level item mean scores, administered at the beginning and at the end of the semester to the students in the experimental group

\begin{tabular}{lcc}
\multicolumn{1}{c}{ The items whose mean scores have not changed } & $\begin{array}{c}\text { Pre-test } \\
\text { mean scores }\end{array}$ & $\begin{array}{c}\text { Post-test } \\
\text { mean scores }\end{array}$ \\
\hline 2. I think people from other cultures are narrow-minded. (Reverse Code) & 4.47 & 4.44 \\
8. I respect the values of people from different cultures. & 4.48 & 4.58 \\
10. I feel confident when interacting with people from different cultures. & 3.84 & 3.88 \\
12. I often get discouraged when I am with people from different cultures. & 3.83 & 4.06 \\
(Reverse Code) & 3.78 & 4.13 \\
13. I am open-minded to people from different cultures. & 4.39 & 4.39 \\
14. I am very observant when interacting with people from different cultures. & & \multicolumn{2}{|c}{} \\
\hline
\end{tabular}


As it is seen in Table 8, it is understood that there was not any change in the levels of six items, when the pretest and posttest item means of these items are compared. In other words, if the student strongly disagreed in the pretest, that student strongly disagreed in the posttest, too.

\section{Discussion and Conclusion}

Intercultural sensitivity perception level of second grade students in English was found to be higher in both experimental and control group students. The increase in the perception level of intercultural sensitivity is explained as the effect of the experimental process in the experimental group. However, the increase in the control group at the end of the period may be interpreted as the effect of different variables affecting the cultures. It will also be misleading to try to explain the development of intercultural sensitiveness, depending on just one factor, such as the educational program because many factors including the previous experiences affecting the development of cultures of cultures, the interaction with different cultures, prejudices, environment and many factors can be taken into consideration. In the study conducted by Tuncel and Paker (2018), it was concluded that senior English pre-service teachers had high intercultural sensitivity perception.

Based on these findings; It was concluded that intercultural sensitivity education activities integrated with scientific research methods course gains, in other words, the experimental process is effective in providing intercultural sensitivity to students. It has also been found that the course on scientific research methods is an appropriate course in providing enriched learning opportunities and integrating it with culturally sensitive activities. It is also concluded that the nested integration model used in the research is also effective. The scientific research methods course was determined as a course, with its content and outcomes, appropriate with regard to integration with intercultural sensitivity training. Ferguson-Patrick, Reynolds, and Macqueen (2018) in their study titled "Integrating curriculum: a case study of teaching Global Education" tried to determine the difficulties and opportunities of the integrated curriculum. They emphasized the significance of global education and intercultural understanding to meet the learning needs of the twenty first century. In addition, they asserted that the teachers are under the pressure of the discipline based teaching approach, and therefore the teaching of the curricula integrated with the qualifications and content required by the twenty first century should first start with the training of prospective teachers. A study by TarabanGordon and Page (2017) revealed that an intercultural skills course integrated with a 20 -hours online professional skills curriculum positively affected the students' intercultural competence perception levels, according to the pretestposttest results. It was concluded that using online learning tools supported the students' intercultural competence development.

Although the majority of the students stated they agreed with the view "I get upset easily when interacting with people from different cultures (Reverse Code)" before the procedure, most of the students stated that they disagreed this view. While most of the students answered another view "I avoid those situations where I will have to deal with culturallydistinct persons (Reverse Code)" as partially agree, they presented their opinions as "strongly disagree" after the procedure. These findings indicate that the activities in the study increased students' self-confidence about their intercultural communicative competences. Li (2017) concluded that the English training program, to which the intercultural competence learning and teaching were planned systematically and integrated, increased both students' learning motivation and self-confidence about their intercultural communicative competences.

While the students answered the scale item, "I think my culture is better than other cultures. (Reverse Code)" as "agree" before the experiment, they presented their opinions as "disagree" after the procedure. Depending on this finding, it can be argued that the activities about reviewing and comparing different cultures, conducted in the experimental group, arose critical cultural awareness in the students. Intercultural sensitivity also indicates the will of an individual not to assume their values, beliefs and behaviours the only correct ones, and to see these from the viewpoint of individuals with different values, beliefs and behaviours (Byram, 1997). While the great majority of the students answered the item "I try to obtain as much information as I can when interacting with people from different cultures" as "partially agree", they presented their view as "strongly agree" after the procedure. This indicates that the students became aware, during the activities, that having limited knowledge about a certain culture would not be sufficient for intercultural interaction. Özdemir (2004) investigated the pre-service teachers' attitudes towards different cultures. As a result of the study, it was determined that English teaching students were willing to explore different cultures but did not create an opportunity. In this study, this situation was interpreted as the fact that English language teaching students were not prepared to meet verbal and nonverbal communication and interaction environment.

The findings of this study may draw the attention of program development experts in the context of revealing the effectiveness of the integrated program. It can help to design more effective training programs in developing intercultural awareness. They can inform the program developers about the activities that will develop intercultural sensitivity and encourage them to think about their role in ELT and the concept of intercultural sensitivity.

Especially, in the development of intercultural sensitivity of English teachers in Turkey, integrated program model applied in this study sample can be used in curriculum development. Because the results in the present study also shows that integrated way which is applied by using the nested model is successful. 
Based on the results of the study, it may be recommended that intercultural sensitivity development training should be administered by integrating it with the scientific research methods course. As it is considered that the scientific research methods course is present in all graduate programs, it can be argued that it would be an effective way to provide students with intercultural sensitivity, too. In addition, studies may be conducted to determine the effects of developing and implementing the interdisciplinary integrated curriculum model or different integration models to develop intercultural competence or intercultural sensitivity. The results of this study could be supported by qualitative data and more in depth explanatory information on integrated activities could be obtained.

This study is limited to determining the intercultural sensitivity development and students' intercultural sensitivity perception, which imply the emotional dimension of intercultural competence. Therefore, the results of the study do not provide information whether the students would exhibit intercultural sensitivity in actual circumstances. The study is also limited to the intercultural sensitivity development activities that can be integrated with the scientific research method course outcomes. The lack of qualitative data collection tools, such as observations and interviews, which may reveal the effects of the integrated program implementation more deeply, is an important limitation of this research.

\section{References}

Auernheimer, G. (2008): Interkulturelle kommunikation, mehrdimensional betrachtet, mit konsequenzen für das verständnis interkultureller kompetenz [Intercultural communication, multidimensional, with consequences for the understanding of intercultural competence]. In G. Auernheimer, (Ed.), Interkulturelle kompetenz und pädagogische professionalität [Intercultural competence and pedagogical professionalism] (pp. 35-65). Wiesbaden: Verlag fur Sozialwissenschaften

Ayvaz-Tuncel, Z. (2009). Bütünleştirilmis program uygulamasının ilköğretim 4. Sinıf öğrencilerinin sosyal gelisim becerilerine etkisi [Effects of an integrated curriculum implementation on the social development skills of 4th grade elementary education students] (Unpublished doctoral dissertation). Hacettepe Universitesi Sosyal Bilimler Enstitüsü, Ankara, Turkey.

Baykara B. (2010). Yabanci dil egitiminde kulturlerarasilik [Interculturalism in foreign language education] (Unpublished master's thesis). Firat Universitesi Sosyal Bilimler Enstitüsü, Elazig, Turkey.

Bulduk, S., Tosun, H. \& Ardıç, E. (2011). Türkçe kültürlerarası duyarlılık ölçeğinin hemşirelik öğrencilerinde ölçümsel özellikleri [Measurement properties of Turkish intercultural sensitivity scale among nursing students]. Turkiye Klinikleri J Med Ethics, 19(1), 25-31.

Büyüköztürk, S. (2018). Sosyal bilimler için veri analizi el kitabi: Istatistik araştırma deseni, SPSS uygulamları ve yorum [Data analysis manual for Social sciences: Statistics research design and applications of SPSS review]. Ankara: Pegem Yayinlari.

Byram, , M., Gribkova, B. \& Starkey, H. (2002). Developing the intercultural dimension in language teaching: A practical introduction for teachers. The Council of Europe. Retrieved from http://lrc.cornell.edu/director/intercultural.pdf

Byram, M. (1997). Teaching and assessing intercultural communication competence. New York: Multilingual Matters. Retrieved from https://books.google.com.tr/books?id=0vfq8JJWhTsC\&printsec=frontcover\&hl=tr

Byram, M. (2009). Intercultural competence in foreign languages The intercultural speaker and the pedagogy of foreign language education. In D. K. Deardorff (Ed.), The SAGE handbook of intercultural competence (pp. 321-332). California: Sage

Chen, G. M., \& Starosta, W. J. (2000). The development and validation of the intercultural communication sensitivity scale. Human Communication, 3, 1-15. Retrieved from https://digitalcommons.uri.edu/cgi/viewcontent.cgi?article=1035\&context=com_facpubs

Council of Higher Education (Yüksek Ögretim Kurumu) (2011). Türkiye yüksekögretim yeterlilikler çerçevesi (TYYC) temel alan yeterlilikleri [Turkey higher education qualifications :general competencies]. Retrieved from http://tyyc.yok.gov.tr/?pid=48

Deardorff, D. K. (2004). The identification and assessment of intercultural competence as a student outcome of internationalization at institutions of Higher Education in the United States (Unpublished Doctoral Dissertation). North Carolina State University, Raleigh, USA.

Deardorff, D. K. (2006). Interkulturelle kompetenz - schlüsselkompetenz des 21. jahrhunderts? [Intercultural competence key competence of the 21st century?] Thesenpapier der Bertelsmann, Stiftung: Gutersloh. Retrevied from https://www.jugendpolitikineuropa.de/downloads/22-177-414/bertelsmann_intkomp.pdf.

Demirel, O. (2004). Eğitimde program geliştirme [Curriculum development in education]. Ankara: PegemA Yayıncılık

Dooly, M. (2010). Shopping across the (EU) market: teacher trainees look for experience abroad. Language and Intercultural Communication, 1(1), 54-71. 
Dooly, M., \& Villanueva, M. (2006). Internationalisation as a key dimension to teacher education. European Journal of Teacher Education, 29(2), 223-240.

Drake, S. M. (1993). Planning integrated curriculum. Virginia: ASCD.

Ferguson-Patrick, K., Reynolds, R., \& Macqueen, S. (2018) Integrating curriculum: a case study of teaching Global Education, European Journal of Teacher Education, 41(2), 187-201. doi: 10.1080/02619768.2018.1426565

Fogarty, R. (1991). Ten ways to integrate curriculum. Educational Leadership, 49(2), 61-65.

Fogarty, R. (2002). How to integrated curricula. Illinois: SkyLight Proffesional Development.

Gencer, 0. (2009). Eğitim fakülteleri alman dili egitimi anabilim dalı derslerinde yabancı kültürle karşilaşma ve önyargilar. ampirik ve nitel bir çalişma [Comparing foreign culture and prejudices in the courses of German language education in the faculties of education. an empirical and qualitative study] (Unpublished master's thesis). Çanakkale Onsekiz Mart Universitesi Sosyal Bilimler Enstitüsü, Çanakkale, Turkey.

Güven, S. (2015). EFL learners' attitudes towards learning intercultural communicative competence (Unpublished master's thesis). Bilkent University, Ankara, Turkey.

Harmandaoğlu, E. (2013). Promoting intercultural competence of teacher trainees in english language departments via web 2.0 tools: A case study (Unpublished master's thesis). Gazi University, Ankara, Turkey.

Hesse, H. -G., \& Göbel, K. (2007). Interkulturelle kompetenz [Intercultural competence]. In B. Beck, \& E. Klieme (Eds.), Sprachliche kompotenzen konzepte und messung [Linguistic competencies concepts and measurement] (pp. 256272). Weinheim und Basel: Beltz Verlag.

Hirotani, M., \& Fujii. K. (2015). The integration of a three-year-long intercultural collaborative project into a foreign language classroom for the development of intercultural competence. In F. Helm, L. Bradley, M. Guarda, \& S. Thouësny (Eds), Critical CALL - Proceedings of the 2015 EUROCALL Conference, Padova, Italy (pp. 235-242). Dublin: Research-publishing.net. http://dx.doi.org/10.14705/rpnet.2015.000339

Jacobs, H. H. (1989). Interdisciplinary curriculum: Design and implementation. Alexandria, VA: ASCD

Jing, H. (2013). Global awareness: Foreign language teachers' beliefs and practices. Intercultural Communication Studies. XXII: 1, 95-116. Retrieved from https://web.uri.edu/iaics/files/9Hongtao-Jing.pdf

Karasar, N. (1994). Bilimsel araştırma yöntemi [Scientific research method]. Ankara: 3A Araştırma, Eğitim Danışmanlık Ltd. Sti.

Kostková, K. (2011). Assessment of intercultural communicative competence. In T. Janík, P. Knecht, \& S. Šebestová (Eds.), Smíšenýdesign v pedagogickém výzkumu: Sborník př́spěvků z 19. výroční konference České asociace pedagogického výzkumu [Mixed design in pedagogical research: Proceedings of the 19th annual conference of the Czech pedagogical research association] (pp. 168-174). Brno: Masaryk University. Retrieved from https://www.ped.muni.cz/capv2011/sbornikprispevku/kostkova.pdf

Larzen-Östermark, E. (2009). Language teacher education in Finland and the cultural dimension of foreign language teaching- a student teacher perspective. European Journal of Teacher Education, 32, 401-421.

Li, Lanping (2017). Systematically planning and integrating intercultural communicative competence learning/teaching into the EFL curriculum/classroom to promote students' learning motivation and confidence in ICC (Unpublished master's thesis). The University of Waikato, China

Malazonia, D., Maglakelidze, S., Chiabrishvili, N., \& Gakheladze, G. (2017). Factors of students' intercultural competence development in the context of Georgia. Cogent Education, 4(1), 1-17. doi:10.1080/2331186X.2017.1302867

McRae, N. \& Ramji, K. (2017). Intercultural competency development curriculum: A strategy for internationalizing work-integrated learning for the 21st century global village, In T. Bowen , Maureen T. B. Drysdale (Eds.) WorkIntegrated learning in the 21st century international perspectives on education and society, Volume 32, pp.129 - 143 Emerald Publishing Limited, UK. Retrieved from https://books.emeraldinsight.com/resources/pdfs/chapters/9781787148604-TYPE23-NR2

Ministry of National Education (Milli Eğitim Bakanlı̆̆ı) (2008). Ögretmen yeterlikleri ögretmenlik mesleği genel ve özel alan yeterlikleri [Teacher competencies, general and special field competencies of the teaching profession]. Ankara: Devlet Kitapları Müdürlüğü

Özdemir, E. (2004). Attitudes of Turkish pre-service English language teachers towards other cultures in intercultural communication context (Unpublished master's thesis). Istanbul Üniversitesi Sosyal Bilimler Enstitüsü, Istanbul.

Papiniu, S. (2016). Interkulturelle kompetenz als integrierter Bestandteil der germanistischen ausbildung in Moldau. Eine empirische analyse von einflussfaktoren [Intercultural competence as an integral part of German education in 
Moldova. An empirical analysis of influencing factors] (Unpublished doctoral dissertation). Philosophischen Fakultät der Georg-August-Universität, Gottingen, Germany.

Sercu, L. (2006). The foreign language and intercultural competence teacher: the acquisition of a new professional identity. Intercultural Education, 17, 55-72.

Sıkı, E. (2014). Yabanci dil öğretiminde kültür farkındalığı yaratma ve kültürlerarası iletişim becerilerinin geliştirilmesi [Creating cultural awareness and improving intercultural communication skills in foreign language teaching] (Unpublished master's thesis). Marmara University, Istanbul.

Spitzberg, B. H. \& Changnon, G. (2009). Conceptualizing intercultural competence. In D. K. Deardorff (Ed.), The SAGE handbook of intercultural competence (pp. 1-52). California: Sage

Tang, S. Y. F. \& Choi, P. L. (2004). The development of personal, intercultural and professional competence in international field experience in initial teacher education. Asia Pacific Education Review, 5(1), 50-63.

Taraban-Gordon, S. \& Page, E. (2017). Integrating intercultural competencies into the professional skills curriculum. In G. M. García-Pérez \& C. Rojas-Primus (Eds.) Promoting intercultural communication competencies in Higher Education (pp. 119 - 139) Retrieved from https://www.igi-global.com/chapter/integrating-interculturalcompetencies-into-the-professional-skills-curriculum $/ 171812$

Tuncel, İ. \& Paker, T. (2018). Effects of an intercultural communication course in developing intercultural sensitivity. International Journal of Higher Education, 7(6), 198-211. doi:10.5430/ijhe.v7n6p198

Turan, S. (2015). Interkulturelle differenzen und kulturbedingte konflikte im fremdsprachenunterricht. Eine empirischqualitative untersuchung (Unpublished master's thesis). Çanakkale Onsekiz Mart University, Çanakkale, Turkey.

Üstün, E. (2011). Ögretmen adaylarının kültürlererası duyarlıllk ve etnikmerkezcilik düzeylerini etkileyen etmenler [Factors affecting teacher candidates' intercultural sensitivity and ethnocentrism levels] (Unpublished master's thesis), Yıldız Teknik University, Istanbul, Turkey.

Yeşilpınar-Uyar, M. (2016). Bütünleştirilmiş program çalışmalarına yönelik yurtdışı eğilimlerin belirlenmesi [Determining the international trends towards integrated program studies]. In Ö. Demirel \& S. Dincer (Eds.), Eğitim bilimlerinde yenilikler ve nitelik arayışı (pp.45-64). Ankara: Pegem Akademi Yayincilik

Yücel, N. (2016). Toward intercultural teacher education: A case study of pre-service english language teachers (Unpublished Doctoral Dissertation). Çanakkale Onsekiz Mart University, Çanakkale, Turkey. 